\title{
Dutch Colonial Anthropology in Indonesia
}

\author{
Léon Buskens ${ }^{a}$ and Jean Kommers ${ }^{b}$ \\ ${ }^{a}$ Faculty of Arts, Leiden University \& Faculty of Law, Utrecht University \\ ${ }^{\mathrm{b}}$ Department of Cultural Anthropology, Radboud University, Nijmegen
}

\begin{abstract}
Attempts to assess the results of colonial anthropology in Indonesia faced some problems, which, until recently, have not been dealt with properly. Therefore, in a newly published comprehensive history of anthropology in the Netherlands, several studies focused on the character, rather than on the substance of colonial anthropology. In the case of Dutch colonial representations of Indonesia, 'colonial anthropology' appears to be an assemblage of various disciplines that constituted a fragmented whole (Indologie; Dutch Indies Studies) from which today's Dutch academic anthropology emerged. However, projection of current conceptions of anthropology into the colonial past resulted in a tendency to neglect some major characteristics of early representations that are imperative for the interpretation of these representations. Besides, a rather limited familiarity amongst present-day anthropologists with the way in which Dutch colonial politics became immersed in international discourses resulted in misappraisal of an essential change in colonial knowledge: the shift from local to analytical representations, deeply affecting the portrayal of Indonesian cultures. In colonial knowledge production, emphasis moved from ethnographic particularism to essentialist conceptions like 'Knowledge of the Native'. This shift also had serious consequences for the academic position of ethnology amongst other colonial disciplines. Until recently, this misappraisal could escape notice because students of Dutch colonial anthropology were insufficiently aware of the effects on interpretation of the great variety of disciplinary discourses, so characteristic for Dutch colonial studies. Therefore, we will here concentrate on these effects and on the growing intertwinement of knowledge and politics which was directly related to the international orientation of colonial policy that became increasingly prominent after the mid-nineteenth century.
\end{abstract}

\section{Keywords}

Indonesia, history of anthropology, Islam, colonial knowledge production, representation, colonial policy and practice

\section{Introduction}

In a recently published comprehensive historical overview of Dutch anthropology, Tales from Academia (Vermeulen \& Kommers, 2002), several articles were devoted to colonial ethnography. Most of these focused on the nature of 
that anthropology — as later turned out implicitly equated with anthropology of Indonesia ${ }^{1}$ - rather than on analysis of its results.

There appeared to be a special need for this subject, for, as Sjoerd Jaarsma, one of the contributors, stated:

'Although there is no shortage of studies in The Netherlands on the historical development of ethnology or (cultural and social) anthropology, attention paid to colonial ethnography as such has been limited.... As a result rosy-coloured descriptions of the part played by ethnology in the training of Dutch colonial civil servants by foreign anthropologists... have long remained unchallenged....' (Jaarsma 2002,815)

This idea of civil servants thoroughly trained in anthropology reaches back well into the nineteenth century (Money, 1861; Steyn Parvé, 1861). On the one hand, it resulted from optimistic interpretations of the curriculum for the training of civil servants, in which ethnology (land-en volkenkunde) seemed to play an important part. After the independence of Indonesia, this training, called Indologie (literally: knowledge of the East Indies), was transformed into anthropology (Schefold, 2002). Thus, still today many Dutch anthropologists who are not well acquainted with colonial history, tend to project current anthropological views straight into this complex past, assuming a direct continuity. ${ }^{2}$

On the other hand, in that past the idea of a close relationship between ethnology and local administration was encouraged by the civil servants' exclusive claims to 'knowledge of the native' (Francis, 1856). As the civil service (called the Corps Binnenlands Bestuur or Corps B.B.) turned more and more into a self confident, and even arrogant corps d'elite at the beginning of the 20th century, identifying itself with the so-called ethical policy, doubts about those exclusive claims to 'knowledge of the native' were no longer tolerated. Until then these claims were contested from various sides, for instance by landowners or traders, as appears from a fierce lampoon culture that was prominent in late 19th century colonial literature. The debate reached a climax in

1 Immediately after the completion of the manuscript Prof. Hoetink rightly concluded that the West Indies (Surinam, the Antilles) had almost completely neglected and that the various institutional histories were too much Indonesia-centered.

${ }^{2}$ Here, it may be interesting to note that in 1977 there was a lot of confusion when the British anthropologist Adam Kuper suggested his Dutch colleagues to commemorate this year as the centenary of Dutch anthropology. It came as a surprise. Nobody had thought of Veth, who was appointed the chair of 'Geography and Ethnology' in 1877, a matter qualified by Van der Velde (2002:666) as 'shameful'. 
the 1920s, when at a congress the matter was explicitly related to the identity of the Corps B.B. (Bertsch, 1938).

Kennis van den Inlander ('Knowledge of the Native') was essential in political rhetoric. By claiming an exclusive position concerning the acquisition of this knowledge, civil servants tried to extend their authority, even to military matters touching the relationship with various peoples all over the Archipelago.

This idea of a prominent command of knowledge about Indonesian peoples reflected a tendency that is also traceable in other colonial policies. The presumed close relationship between increasing empirical knowledge of indigenous cultures and the growing sophistication of colonial government may be considered a crucial aspect of colonial state-formation. In fact, this relationship often appeared an illusion, as argued, for instance, in Harrison's study concerning French colonies. Knowledge production, which according to scientific standards should be impartial, in fact was dominated by politics. That is why local data, as we shall see when discussing documents related to the transfer of offices, were generally ignored. That is also why, as stressed too by Harrison, local civil servants left unused whole libraries or applied local knowledge wholly arbitrarily (Harrison 1988: 97, 127, 148-149; for an extensive discussion: see Kommers 1993 b). It is also why ethnological theories which often did not fit the ideas inherent in current policies lacked regard, among civil servants as well as among students of Islam or of native law (Adat). Many of the illusions and paradoxes noted by Harrison can equally well be detected in the development of knowledge production as an aspect of state formation in the Dutch East Indies. In this respect the situation in this colony only seems to be one more confirmation of the importance of what Edward Said (1978) conceptualized as 'textual attitude'. As such we may consider the case of anthropological knowledge production in the Dutch East Indies as representing an international trend in colonial politics, resulting in scaling up of social dimensions and related to broadly experienced problems, such as the 'threat' of pan-Islamism. On the other hand, the academic world in the Netherlands was far from being the servant of colonial politics. Its internal dynamics appears to be characterised by an almost bewildering diversity of mutually exclusive disciplinary sects, each with their own sub-discourses.

The above-mentioned idea of ethnologically oriented colonial officials, as well as a conception of anthropology that indiscriminately incorporates other disciplines, was already object of criticism during the late colonial period (Fischer, 1931; Held, 1953). However, the discussion got a special meaning in the 1970s during the so-called anti-colonialism debate when anthropology was proclaimed the 'handmaid' of colonialism. The imagined close relationship between anthropology and colonial policy and practice now turned out 
to be very unfavourable for anthropology that had to bear a moral burden. During the discussions that followed special attention was directed to disciplinary boundaries and to attempts to define the various discourses in diachronic perspective. Thus, the relationship between 'knowledge of the native' and ethnographic knowledge became subject to scrutiny (Kommers, 2002:760-764). To outsiders these matters may seem only of academic interest, but in the Netherlands they are very sensitive as may be inferred from the various contributions to Tales from Academia. The discussion is also closely linked to ideas about the practical value of anthropology, an issue that reaches back into the colonial period, when ethnology was considered interesting but unpractical (compare the polemical discussion by Huizer, 1999:44). At times ethnography was even considered inaccessible: characterized by 'dry' language, in contrast to the 'real' knowledge of the people that supposedly was worded in 'vivid images' (gambar hidoep as the prominent civil servant Damsté (1918:438) called this style). As we will show, this literary aspect deeply influenced interpretations. In their turn these interpretations contributed much to mutual attitudes between the various colonial disciplines, like Adat-law studies, or Islamic studies. Therefore we question the statement made by Franz and Keebet von Benda-Beckmann (2002: 696) that 'it was not so much the interest in different kinds of ethnographic information but rather the reasons for collecting them and the uses to which they were put that distinguished Dutch ethnology and adat law studies in the colonial period.' In our view, the forms used in the presentation of this information were at least as important as its instrumental aspects. Indeed, what was considered 'ethnographic information' and the social relevance attached to it was highly dependent on interpretation which in its turn was closely linked to disciplinary conventions as expressed by (among other things) literary traditions.

In this article we will pay attention to this discussion about disciplinary relationships, trying to understand why matters concerning the development of the nature of colonial anthropology, rather than an assessment of substance and anthropological quality of colonial ethnology and ethnography, dominate current debates. If anthropological research really was that important in colonial policy and practice, why did all these efforts not result in at least some anthropological classics; i.e.: in ethnographies which became part of the international anthropological canon (see Trouwborst, 1993, 1996)? Why was criticism of the myriads of pages with ethnographic data from anthropologists at times so severe and even depreciating (see e.g. Blok \& Boissevain, 1984)? 


\section{Problems in Assessing Dutch Colonial Anthropology}

In 1975 Koentjaraningrat published his extensive and thorough Anthropology in Indonesia. A Bibliographical Review. We may consider this book as an attempt to assess the contents and scope, as well as the quality of 'colonial anthropology'. Immediately at the start of his study, Koentjaraningrat faced two problems: first the problem of disciplinary identities, and second the question of criteria by which to review the quality of colonial literature about Indonesian peoples and cultures. Both problems are still topical. In current debates, as presented in Tales from Academia, the view seems to prevail that the matter of quality assessment cannot be tackled adequately, before Koentjaraningrat's first problem has been solved. Indeed, to escape anachronistic conclusions, insight into the historically grown relationships between disciplines that at first sight seem closely related is imperative (Trouwborst, 2002:673-694). This brings us to the nature of these disciplines: their particular discourses, stylistic conventions, political positions, mutual relationships. In short: to a great variety of phenomena which deeply influenced interpretations that guided colonial as well as post-colonial analyses.

In his assessment of the quality of ethnographic sources Koentjaraningrat started from current positivist ideas about the reliability and validity of the sources. This severely limited his view, especially concerning the pre-20th century ethnography, and resulted only in a list of 'frequent failings of such writings' (see Koentjaraningrat, 1975:20-23). His conclusions are in line with those worded in the 1940s by the anthropologist Nooteboom (1940). Most early ethnological writings are characterized as 'generally of poor quality'. According to Koentjaraningrat the earliest writings should be considered 'useless for the purposes of anthropological analysis'; a statement he illustrates by referring to Valentyn's 18th century compendium. ${ }^{3}$ Concerning the development after 1860, he diagnosed 'some improvement ... as several people started to compile bibliographies while others began to integrate the vast amount of ethnographic data'. But regarding the articles written in those days by civil servants, he could only conclude that these were 'no more than factual reports' (Koentjaraningrat, 1975:1, 18). However, those works that he considered compilations of ethnographic data (mostly in handbooks, a genre that was popular at the turn of the century), implied fundamental generic transformations, moving them far from locally oriented ethnography (compare Buskens, 1992). Koentjaraningrat's approach of ethnographic texts was in line with a

${ }^{3}$ Recently (2002-04), a reprint of the complete work was issued in 8 folio volumes, accompanied by a monograph on Valentyn and his book, illustrating a reappraisal of this 18 th century document. 
view expressed by A.N.J. den Hollander, a foremost Dutch sociologist, who in that period wrote authoritative positivist essays about ethnographic representation (Den Hollander, 1968 ${ }^{4}$ ).

As indicated before, the first problem encountered by Koentjaraningrat is also still topical: how to define 'colonial anthropology'? As Koentjaraningrat (1975:VII) rightly stated, if one would start from the conventional meaning of anthropology as an academic discipline, the anthropology of Indonesia would encompass only a few authors. There would be no such phenomenon as 'colonial anthropology'. However, by incorporating the representatives of other disciplines like linguistics or Islamic Studies, a lot of problems arise. Problems that touch on the already noticed ethical issues, but which also, because of 'unnoticed' blurring of genres, result in serious difficulties of interpretation. The ethical question was raised most prominently in relation to Wertheim's article on counter insurgency that appeared in 1972, but the matter still was an issue in 1997, when Pels published an assessment of the relationship between anthropology and colonialism in the Annual Review of Anthropology.

In this article we will now first discuss more extensively the relationships between the various disciplines and discourses formerly lumped together under the name of 'colonial anthropology'. In this way we can identify the interpretational problems that are faced by current historical analyses. After that we will focus on the development of one particular field: the study of Islam in connection with the Delft institute for the training of civil servants. This sketch may offer some insight in the social-political background of interdisciplinary relations.

\section{The Story of 'Colonial Anthropology' in Indonesia}

In his contribution to Tales from Academia, Trouwborst (2002) extensively described the mutual relationships between a series of subjects which were formally united under the banner of Indologie (Dutch Indies Studies). Indologie was a program for the education of future civil servants. Over the years it comprised mainly the study of Islam, geography and ethnology (Land- en Volkenkunde), and the study of Malay and Javanese Languages. Later on the study of Native Law (Adat Law) became prominent.

${ }^{4}$ His major essay on ethnography was republished in a handbook about field methods in Anthropology, under the title 'Social description; the problem of reliability and validity', pp. 1-34 in Jongmans \& Gutkind Anthropologists in the Field, 1967. 
Trouwborst's contribution, devoted mainly to the relations between Anthropology, the study of Islam, and Adat Law studies, is unique and of particular interest as he himself studied Indologie when the colonial period was drawing to a close. Besides, when he finished his studies, a career as a civil servant was no longer ahead because of Indonesia's independence. He became a professional anthropologist. So, he could give an insider's view from both sides.

In his contribution he starts from the strict division of labour, as he himself experienced during his studies. This was connected with a fragmentation of knowledge that Ellen (1976) traced back to the beginning of the twentieth century. In fact it continued a situation that came into being during the second half of the nineteenth century when relationships between representatives of the various disciplines were not very close. This, notwithstanding allencompassing titles of subjects taught to civil servants in spé or a multitude of encyclopaedic inventories (Van der Velde, 2002:647-672).

Trouwborst (2002:673) tried to explain the 'mutual avoidance' between representatives of the various disciplines and to trace its implications for the use of anthropology in the colonial administration. However, the relations not only were characterized by this avoidance, in fact the position of ethnology was marginal compared to the other disciplines. For instance, there existed a Kantoor voor Inlandsche Zaken (Office for Native Affairs), but it hardly touched on matters concerning Indonesian cultures. It mainly concentrated on Islamic affairs (Trouwborst 2002:685).

Notwithstanding the fact that the Corps B.B. identified with its exclusive way to approach 'the natives' on an intimate level ('contact' and tournée were key concepts), in practice communication usually was limited to particular representatives of the population. Only rarely the work of civil servants could be compared with anthropological fieldwork à la Malinowski (Pruys van der Hoeven, 1864). If there was any resemblance, mostly this was the case only in the Buitengewesten (Outer Territories; compare Trouwborst, 2002:687). Indeed as the 19th century drew to a close, bureaucratic duties more and more stood in the way of such continuous contact. In his Memories, Djajadiningrat (1936:311-312) characterised the change as one 'van rijpaard tot vulpen' (from riding horse to fountain pen). What is more: as change went on, those who really did fieldwork, like a linguist as Van der Tuuk, ran the risk of being accused of verinlandsen (going native) and sometimes this accusation contained a hidden reference to betrayal, in line with a deep distrust to everything that escaped the civil servant's influence. The ideology of closeness, implied by the key-concept of 'contact', was of course related to the self-proclaimed right 'to speak for the natives'. It fitted the paternalistic attitude with which outsiders characterized the Corps B.B. What is of special importance here is that the closeness was expressed in an authoritative way 
by a particular genre as exhibited most prominently in the works of some literary able civil servants. Their model descriptions about 'life among the natives' reflected the various characteristics of the 'colonial mind' as worded by Johannes Fabian (1983). This genre obeyed to certain literary conventions (see e.g. Doeff, 1896 or Westenenk, 1928). In his preface to a post war edition of such a book, Du Croo's recollections of his life in Het land van-bij-ons buiten (The land of our Outer Territories), Meyer Ranneft, one of the main colonial policy makers of those days, compared him and other authors like Van Vollenhoven, with Kipling 'with his strong control of language' (Du Croo, n.d.: 6-7). Transparency, reduction, côterie-language in the form of certain topoi, stylistic forms like focalising, holistic representations, and naturalistic concepts are main characteristics (Kommers, 2000: 105-132).

It is not surprising that civil servants with this particular kind of contact had difficulties to understand scientific ethnographic descriptions which they experienced as alienating representations, being far removed from their conception of daily life. These descriptions were considered fragmentary because of their lack of textual organizing principles that could suggest wholeness and vividness. In recent debates, these literary qualities have often been overlooked. Thus, in assessing the international importance of Veth's Borneo's Wester-Afdeeling: Geographisch, Statistisch, Historisch (1854-56; 'Borneo's Western Division: Geographical, Statistical, Historical') Vermeulen (1996:37, see Van der Velde 2002:656) referred to its theoretical orientation. However, according to contemporary evaluations, its language, offering tafereelen die kleurschakeringen teekenen instead of dorre schetsen (scenes depicting shades of colours instead of dry sketches) was at least as important for its reception (see Veth, 1854:ii; compare also Huigen 1998).

It is no coincidence that contemporary comments on ethnography often concentrated on style and language. During their training civil servants had to learn by heart encyclopedic overviews about Land-en Volkenkunde (Geography and Ethnology), some of which, like Keijzer's condensed re-edition of Valentyn's 18th century compilation (Keijzer, 1856-58), were quite archaic. Apart from stimulating aversion to this kind of literature (see Fasseur, 1993), it represented Indonesian cultures from a distance. Not only was 'real life' lacking, these compilations also were the result of transformations of ethnographic descriptions, which during this process lost their couleur locale.

Perhaps the authority attached in 19th century Academia to such representations 'from a distance' may also explain why a person like Veth, who never visited the East Indies, could attain the status of a major specialist on Indonesia, a question that Van der Velde treated as 'fascinating' (compare his explanation, 2002: 648). 
At first sight it may seem paradoxical that the 'vivid' descriptions in which 'knowledge of the natives' was embedded, hardly represented local qualities. However, this was in line with a general tendency in representations of Indonesian cultures that started around the middle of the nineteenth century and that accelerated after the 1870s when the Dutch population in Indonesia grew rapidly and colonial society and patterns of intercultural communication changed. Next to the detailed locally oriented descriptions, qualified by Koentjaraningrat as 'no more than factual reports' and mostly presented in Memories van Overgave (statements produced at the transfer of duties to a new officer ${ }^{5}$ ), a new kind of literature about 'native life' originated. Representatives of various professions and disciplines started to produce descriptions of native life that were strongly experiential in character and that often had a personal touch. Rather than claiming authority in matters of policy, these writings reflected insight into 'how to deal with the natives' in daily routine (SzékelyLulofs, n.d.). Therefore they were not considered threatening the monopoly of the civil servant's unique position like the politically oriented writings of competitors of the Corps. Because of their strong common sense quality, this new genre offered forms that were very adequate to present instrumental knowledge of the natives, a kind of knowledge that also seemed imperative to attain one of the central objectives of the Binnenlandsch Bestuur in those days: to secure rust en orde (peace and order).

This literature sharply contrasted ethnography per sé: it was generalising rather than localising. It reflected a fundamental transformation in the representation of the Other. 'Knowledge of the natives' (plural) became, as it was literally called, kennis van den Inlander: 'knowledge of the Native' (singular). This expression implied standardisation, even stereotypisation. On the one hand, naturalistic and realistic descriptions organised in a way suggesting holism, seemed to approach 'real life as it was lived by the natives'. On the other hand, standardisation resulted in the reduction and transparency that paved the way for the idea that one really could know the natives.

'The native', of course, was a construct that fitted other generalising conceptualisations connected with late 19th century imperialist tendencies. This change in representation of the Other was not only related to changes in

${ }^{5}$ Here it may be interesting to note that sometimes the suggestion was made to use these memories as instruction material for future civil servants, but the idea was rejected, because the literature was considered unfit (See Steinmetz 1888: 179). In the main periodicals for the Civil Service complaints are abundant that local information compiled in the Memories remained unused or was neglected. However, the cause of the 'neglect' remained unmentioned (see Keijzer 1856 , introduction to vol.1. The problem was not confined to Dutch colonial policy, see Harrison, who concluded that whole libraries remained unused: 1988: 4, 135. 
colonial society, but also to developments in the mother country. As Legêne (2002:629-635) indicates, in the Netherlands during the 19th century, attitudes to colonial expansion were closely related with the process of stateformation which had a specific character after the independence of Belgium. These attitudes are reflected in the classification of ethnographic objects from the colonies in museum collections, as well as in the (sub)academic programs for the education of civil servants. In the next section we shall elaborate this aspect by discussing the development of Islam studies in a wider social context. Here we may conclude that during the second half of the 19th century a widening gap became visible between locally oriented ethnography and practically or instrumentally oriented 'knowledge of the Native'. As both kinds of 'information' were closely related to literary forms, governed by specific generic conventions that were crucial for interpretation, this development was at the very root of the mutual avoidance between the 'indological' disciplines that Trouwborst, (2002:673) experienced so strongly.

Of course, this 'literary' aspect is only one of various factors making up the specific disciplinary traditions or discourses, but it can explain many misunderstandings (or misinterpretations) that caused poor interdisciplinary relations. For instance when generic characteristics remained misunderstood, comments could be severely critical, like in the case of Snouck Hurgronje's De Atjèhers (1893-1894). This monograph displays a blurring of genres and consequently evoked different kinds of criticism from various types of readers. Thus, for instance, to policy-makers, specific ethnographic details qualified by the author as important for understanding political relations, could be only burdensome minutiae. This 'blurring of genres' may explain why this impressive monograph, notwithstanding an English translation (Snouck Hurgronje, 1906), did not reach the status of an anthropological 'classic'. This deeply influenced its reception in the late 20th century anti-colonialism debates within anthropology (see e.g. Kommers, 1996; Trouwborst, 1993, 1996). Rather than asses the work in reference to anthropological conventions one should place it in the history of Oriental travel writing and its corresponding literary tradition (Kommers, 2002:762-63).

To summarise the trend, it may be interesting to refer to developments within ethnography. Literary forms supporting colonial representations developed in a way comparable with the shift from 19th century 'multi volume ethnographies' as characterised by Clifford (1988) to the early 'realist tales' analysed by Van Maanen (1988). Standardisation of concepts and internationalisation of colonial debates resulted in what we now call 'etic constructions' like adat law. As realist tales suggest naturalistic and authentic representations, but in fact conventionalised experience and typified 'the Other' (Van Maanen, 
1988:48-51), so did late 19th and early 20th century reports exhibiting 'knowledge of the Native'. Of course there were some significant differences between the two genres. For instance, where realist ethnography implied theory, this was often explicitly rejected in the colonial texts. But pretensions about the representation of the 'native's point of view', transparency, experiential authority, focus on the ordinary, documentary style interspersed with representative anecdotes or cases referring to 'real life' may be considered common denominators. The standardisation resulted in alienation from local, 'experience near' representations (compare Geertz, 1983) that characterised early 19th century ethnography. Thus, the mutual avoidance between 'anthropology' and the other colonial disciplines, as experienced by Trouwborst and confirmed by Franz and Keebet von Benda Beckmann, not only has to do with reasons for collecting and uses made of ethnographic data as the Von Benda Beckmanns stated, but should also be connected with representational genres that separated the disciplines and that paved the way to many a misunderstanding or normative view. The importance of this 'literary' dimension is also underlined by the fact that those who are generally considered as the protagonists of the major colonial disciplines, Snouck Hurgronje and Van Vollenhoven, displayed strong literary qualities (compare Geertz 1988).

\section{Colonial Representation: Civil Servants and the Study of Islam in the 19th Century}

In recent criticisms of colonialism in Indonesia, Dutch anthropologists mainly concentrated on Snouck Hurgronje, who was considered the symbol par excellence related to the theme 'anthropology and colonial repression'. As for instance Pels stated: 'Professional ethnography... may be better regarded as a specific offshoot of a wider field of colonial intelligence rather than... the fulfilment of an intellectual goal to which colonial ethnographies vainly aspired' (Pels, 1997:167). In this field of colonial intelligence, according to him, Snouck Hurgronje stood out.

The argument was mainly based on the incorporation of Snouck Hurgronje into the community of anthropologists, notwithstanding his own reticent attitude towards ethnology. As Trouwborst (2002:676) clearly showed, it is 'rather inappropriate to call him an anthropologist'. However, for most late 20th century Dutch anthropologists Snouck Hurgronje was an anthropologist, because of his 'fieldwork' in Mekka and Aceh. Pels considered strong normative wordings appropriate: 'Military intelligence employed most colourful and ruthless anthropologists... such as... Christiaan Snouck Hurgronje' 
(Pels, 1997:170). In anthropological discussions lack of detailed acquaintance with the work of Snouck Hurgronje was ample compensated by opinions and qualifications referring to his mythical stature that he mainly derived from his sharp and eloquent pen. At the end of the 20th century many anthropologists still tended to jump to conclusions about the character and personality of writers on the basis of their texts. In this case, the personalisation resulted in 'epic concentration' which in particular blocked the view to earlier episodes in the study of 'practical' aspects of Indonesian cultures, like Islamic law. Notwithstanding the Islamofobia that pervaded much of late 19th century colonial policy and practice, and that seems only too topical today, to view the study of Islam and Islamic law mainly in terms of 'colonial intelligence' would be too narrow. It would hinder our insight into wider social contexts within which colonial policy developed in the Netherlands. In many respects this context affected scientific debates and the development of curricula for the education of civil servants. It affected interdisciplinary relationships resulting in the above noted fragmentation and in the delayed reception of colonial studies on Islamic law in postcolonial Dutch anthropology (Buskens \& Kommers, 2002:733-755).

The conception of what Islamic law is or should be, was formed within a social context, reflecting continuity and change in colonial policy, but also in Dutch politics. How Dutch social and political attitudes played a role in representations of (aspects of) Indonesian cultures, representations which in their turn deeply affected colonial policy, may be inferred from the development of Islamic studies at the Delft Academy for the education of civil servants. The history of this Academy, during which the foundations were laid for later developments in Leiden under the aegis of Snouck Hurgronje and Van Vollenhoven, offers a clear view on the connection between socio-political trends and the development of ideas about colonial science. In particular an analysis of the changing attention students of Islam paid to normative rules as included in texts on the one hand, and the norms as lived in daily practice on the other hand, may be helpful to get insight into colonial attitudes to the relationship between the global and the local. Thus, for instance, the prominence given during certain periods to the authority of texts is closely related to ideas about colonial rule and pan Islamic threats. In its turn, this shift in attention affected the status of ethnology and 'experience near' ethnography in academia during the colonial period. Approaches starting from the primacy of texts fitted late 19th century trends towards conceptual standardisation which laid the foundations for constructions like 'Islamic Law' or 'Adat Law' and the emergence of the genre of handbooks in which ethnographic 'data' were 'integrated' (Koentjaraningrat, 1975:1), or rather, transformed (Kommers, 1993 a). 
Professional ethnography of the East Indies hardly played a role in colonial intelligence. Thus, even those ethnographic sections of Snouck Hurgronje's De Atjehers which the master himself considered of great political importance (for instance the description of elders teaching boys how to fly kites), were despised by 'practical men' like civil servants and considered of no practical value (see for an extensive analysis Kommers, 1996). In the field of 'intelligence' ethnology or ethnography was absolutely marginal compared to the practical 'knowledge of the Native' as represented in other genres. Buskens' study of the Delft Academy illustrates the close relationship between this practical knowledge and attempts to create educational textbooks (Buskens 2006). Thus, the first teacher of Islamic Law, Albert Meursinge, used a Malay text to construct a book of Islamic Law to be used '... also by the Native of the East Indian Archipelago', on the condition that this 'Native' is 'enough developed to grasp the course of argument' (Meursinge, 1844:vii).

His successor, Salomo Keijzer, published the first handbook of Islamic Law in Dutch (Keijzer, 1853). Starting point was 'pure' Islamic law, followed by a treatise on local forms of that law as existing in the East Indies, which he considered 'deviations'. In his construction he closely followed the structure of Islamic legal texts, rejecting a European format. At the same time he aimed at serving the practical interests of the colonial administration. In contrast to wide-spread stereotypes Keijzer stated that Muslim societies were governed by order and justice. According to Keijzer, this order was the same everywhere in the (Muslim) world and was based on the same Islamic Law. This view fitted a tendency to link Dutch colonial policy to international discourses. In Keijzer's view normative Islamic texts provided the key to understanding local practices, to be studied by way of fieldwork. Ethnography could identify 'deviations'.

His ideas brought him into conflict with the liberal politician and former Batavian clergyman W.R. van Hoëvell. Contrary to Keijzer, Van Hoëvell considered textual knowledge based on handbooks from the Middle East irrelevant for civil servants, who, according to him had to concentrate on local customs.

Keijzer's successor, A.W.T. Juynboll followed his idea that by studying the principles of Islamic law local 'adaptations' could be understood. All these professors lacked personal experience with the East Indies.

This changed with the appointment of L.W.C. van den Berg. On the one hand, Van den Berg continued the 'doctrinarian' view on the relationship between Islamic law and adapt. On the other hand, he had a major influence on the administration of law by introducing a Western arrangement in the legal regulations of the casuistically structured fiqh texts (Van den Berg, 1874). 
His outspoken views stimulated his academic and political opponents at the Leiden University, Snouck Hurgronje and Cornelis van Vollenhoven to develop a new approach to the relation between Islamic and adat law. In contrast to the 'doctrinary' approach, starting from the primacy of Islamic law to understand local daily life, Snouck Hurgronje and Van Vollenhoven recognised the integrity of adapt. Their Adatrecht-doctrine reflected a new academic as well as legislative-political program, inspired by the so-called ethical policy that came up in the late 19th century in the wake of a.o. Multatuli's indictment of the Cultuurstelsel and in line with the rise of liberalism.

In 1901 the Delft Academy was closed down. Leiden became the centre for the education of Civil Servants.

The shift from Delft to Leiden symbolises a change in political ideas concerning 'how to manage a colony' (Money 1861) to an ideology about 'how to care for the colonised peoples'. 'How to manage a colony' was based on an instrumental 'knowledge of the Native' mainly worded in naturalistic and realist texts describing 'real life'. The Delft approaches aimed at making local diversity understandable from the outside: from general principles, in the end arranged by a European format. The Leiden approach replaced current representations by far more complicated ones which, at least in principle, intrinsically respected local forms.

It is interesting to note that critics of the 'Leiden school', among whom many civil servants who received their training at Delft, often took refuge into instrumental genres pretending to represent 'real life' in a pragmatic way. This in contrast to the scholarly approach of the 'Leiden school' that got an opponent in the 'conservative' school established at Utrecht in 1925. But by then, changes in the representation of Indonesian cultures had gained a definitive form: the Leiden program would remain dominant during the rest of the colonial period. Its views became canonised in Th. W. Juynboll's Handleiding, first published in 1903 and republished several times until 1943, in which he consistently contrasted textual knowledge of legal rules to social practices.

\section{Conclusion}

Lack of insight in the development of specific disciplinary traditions that resulted in fragmentation of knowledge and in diverging discourses characterised by different generic forms, deeply affected post-colonial interpretations of early representations of Indonesian cultures. This is why attempts to assess the results of Dutch 'colonial anthropology' like Koentjaraningrat's faced serious difficulties which only recently became the subject of analysis. 
Until late in the twentieth century, Dutch anthropologists tended to lump together the results of different colonial disciplines under the heading of 'colonial anthropology'. In the 1970s, so-called critical anthropologists stroke the key by assuming that colonial politics dominated knowledge production. This seemed justified by civil servants claiming to monopolize ethnographic knowledge, as well as by governmental influence on the education of those civil servants. Knowledge prominently seemed to be instrumental: whether it concerned local, ethnographical knowledge, or large-scale ideas like those about Islam. Although there can be no doubt about a close connection between colonial power and knowledge production and the instrumentality of (ethnographic) knowledge, this connection was far from imperative. On the one hand, local ethnographers (-cum civil servants) always remained critical of official images of 'their' peoples. On the other hand, the political influence on knowledge production was constantly contested by scholars, who were also subject to their specific disciplinary discourses. The illusion of knowledge production at the service of colonial power, as held for decades by many postcolonial Dutch anthropologists, justified a homogeneous conception of 'colonial anthropology'. However, the tendency to reduce the results of diverging discourses to a common denominator hid the essential generic and representational characteristics, which are the subject of this article. The theme appears to be vital not only in interpreting colonial writings, but also in understanding the multiple relationships between knowledge and politics as manifest in the vicissitudes of the Delft institute for civil servants' training when politics changed from 'how to manage a colony' to 'how to care for the colonised peoples'.

Dutch colonial representations of Indonesian societies and cultures were embedded in various genres, in some cases related to explicitly labelled disciplines, like 'Ethnology of the Dutch East Indies' or 'Colonial Ethnology', but at times only indicated informally, like 'knowledge of the native/natives'. Historical study shows that differences between those genres, which at first sight may seem subtle, were closely connected with major differences in approaches of Indonesian cultures and could reflect important discrepancies in colonial ideology or politics. Next to colonial politics, the study of representations of colonized peoples should constantly pay attention to 'the politics of writing' which is part of general colonial discourses, as made clear by Edward Said in his classic study which made 'orientalism' almost equivalent with the formation of exotic images (compare Piot 1999). The case of the Dutch East Indies, however, may also stress the importance of studying these general developments within proper historical contexts. 


\section{References}

Bertsch, R.K.A. (1938) “De Kern onzer taak", in V.A.B.B. Congres, pp. 12-17.

Blok, Anton and Jeremy Boissevain (1984) "Anthropology in the Netherlands: Puzzles and Paradoxes", Annual Review of Anthropology 13:333-344.

Buskens, Léon (1993) "Islamic Commentaries and French Codes: The Confrontation and Accommodation of Two Forms of Textualization of Family Law in Morocco", in Henk Driessen, ed., The Politics of Ethnographic Reading and Writing. Confrontations of Western and Indigenous Views. Saarbrücken: Breitenbach Verlag, pp. 65-100.

(2006) "Twee negentiende eeuwse ontdekkers van het Islamitisch recht te Delft. Een begin van het debat over theorie en praktijk", in Paulien van der Grinten \& Ton Heukels, eds, Crossing Borders. Deventer: Kluwer, pp. 153-171.

Buskens, Léon and Jean Kommers (2002) "The Delayed Reception of Colonial Studies on Adat Law and Islamic Law in Dutch Anthropology”, in Vermeulen \& Kommers, eds, pp. 733-755.

Clifford, James (1988) The Predicament of Culture: Twentieth-century Ethnography, Literature and Art. Cambridge (Mass.): Harvard University Press.

Den Hollander, A.N.J. (1968): Visie en Verwoording: sociologische essays over het eigene en het andere. Assen: Van Gorcum.

Damsté, H. (1918) “Gambar Hidoep”, Koloniaal Tijdschrift 7:483-442.

Djajadiningrat (1936) Herinneringen van Pangeran Aria Achmad Djajadiningrat, Amsterdam/ Batavia.

Doeff, H. (1896) In de grenslanden der beschaving. Ervaringen uit het dagelijksch leven van een controleur bij het Binnenlandsch Bestuur in de Buitenbezittingen van Nederlandsch Indië, Amsterdam.

Du Croo, M.H. (n.d.) Het land van bij-ons-buiten. Herinnerigen van een officier-gezaghebber in de Indische buitengewesten. Maastricht.

Ellen, R.F. (1976) "The Development of Anthropology and Colonial Policy in the Netherlands: 1800-1960", Journal of the History of Behavioral Sciences 12(4):303-324.

Fabian, Johannes (1983) "Missions and the Colonisation of African Languages: Developments in the Former Belgian Congo", Canadian Journal of African Studies, 17(2):165-187.

Fasseur, C. (1993) De Indologen. Ambtenaren voor de Oost 1825-1950. Amsterdam, Bert Bakker.

Fischer, H.Th. (1931) "Het belang der volkenkunde voor de koloniale politiek", De Indische Gids 53:1057-1068.

Francis, E. (1856) Herinneringen uit den levensloop van een Indisch' Ambtenaar bij het binnenlandsch bestuur, Batavia.

Geertz, Cl. (1983) Local Knowledge: Further Essays in Interpretive Anthropology. New York: Basic Books.

(1988) Works and Lives: The Anthropologist as Author. Stanford: Stanford University Press.

Harrison, Chr. (1988) France and Islam in West Africa, 1860-1960. Cambridge, Cambridge University Press.

Held, G.J. (1953) "Applied Anthropology in Government: The Netherlands", in A.L. Kroeber, ed., Anthropology Today, an Encyclopedic Inventory, Chicago \& London, pp. 866-879.

Huigen, Siegfried (1998) "Natural history and the representation of South Africa in the eighteenth century", Journal of Literary Studies 14:67-80.

Huizer, Gerrit (1999) Engagement, emancipatie en sociale wetenschappen in een mondiaal perspectief, Nijmegen:KUN.

Jaarsma, Sjoerd (2002) "Changing Practices of Anthropology: Moving from West New Guinea to Papua”, in Vermeulen \& Kommers, eds, Tales from Academia, pp. 815-837.

Juynboll, Th,W. (1903) Handleiding tot de kennis van de Mohammedaansche wet, volgens de leer der Sjafi'itische school. Leiden: E.J. Brill.

Keijzer, Salomo (1853) Handboek voor het Mohammedaansche regt. 's-Gravenhage: Gebr. Belinfante. 
(1856-1858) François Valentyn's Oud en Nieuw Oost-Indië. 3 vols, Den Haag: A.C. Susan. Koentjaraningrat (1975) Anthropology in Indonesia. A Bibliographical Review, The Hague: Martinus Nijhoff.

Kommers, Jean (1993 a) "Koloniale Etnografie", in Paul Haenen \& Albert Trouwborst (eds), Liber Amicorum Alex van der Leeden. Leiden/Jakarta: DSALCUL/IRIS, pp. 49-60.

(1993 b) Words with a certain fixed value: the concepts of primitive and Islam in the colonial literature about West Africa, in Henk Driessen (ed.), The Politics of Ethnographic Reading and Writing. Saarbrücken: Breitenbach.

(1996) "Snouck Hurgronje als koloniaal etnograaf: De Atjèhers (1893-1894)", Sharquiyyât 10(2): 87-115.

- (2000) "Hard Labour: an Anthropologist Analyses Missionary Juvenile Literature", in Ad

Borsboom \& Jean Kommers (eds), Anthropologists and the Missionary Endeavour: Experiences and Reflections, Saarbrücken: Verlag für Entwicklungspolitik, pp.105-132.

- (2002) "Ethnography in the Netherlands East Indies, 1850-1900: Social Change and Representation of Indonesian Cultures", in Vermeulen \& Kommers, eds, Tales from Academia, pp. 757-789.

Legêne, Susan (2002) "Ethnography and Colonialism after 1815: Non-Western Culture and Dutch Cultural Heritage", in Vermeulen \& Kommers, eds, pp. 627-645.

Meursinge, Albert (1844) Handboek van het Mohammedaansche regt, in de Maleische taal; naar oorspronkelijke, Maleische en Arabische werken van Mohammedaansche regtsgeleerden, Amsterdam: Johannes Müller.

Money, J.W.B. (1861) Java, or How to Manage a Colony. Showing a Practical Solution of the Questions now Affecting British India, 2 vols, London: Hurst \& Blackett.

Nooteboom, C. (1940) "Volkenkunde en koloniale praktijk", Koloniaal Tijdschrift 29:393-403; 491-509.

Pels, Peter (1997) “The Anthropology of Colonialism: Culture, History, and the Emergence of Western Governmentality”, Annual Review of Anthropology 26:163-183.

Piot, Charles (1999) Remotely Global: Village Modernity in West Africa. Chicago: Chicago University Press.

Pruys van der Hoeven (1864) Een woord over Sumatra. In brieven verzameld en uitgegeven, 2 vols, Rotterdam.

Said, Edward (1978) Orientalism, London: Routledge \& Kegan Paul.

Schefold, Reimar (2002) "Indonesian Studies and Cultural Anthropology in Leiden: From Encyclopedism to Field of Anthropological Study", in Vermeulen \& Kommers, eds, Tales from Academia, pp. 69-94.

Snouck Hurgronje, C. (1906) The Achehnese. 2 vols, Leiden: E.J. Brill.

Steinmetz, H.E. (1888) Brieven aan een staatsraad. Haarlem: De Erven F. Bohn.

Steyn Parvé, D.C. (1861) “Aanteekeningen” in J.B. Money: Java, of hoe een kolonie moet bestuurd worden, Zutphen.

Székely-Lulofs (n.d.) Onze bedienden in Indie. Deventer.

Trouwborst, Albert (1993) De Atjèhers van Snouck Hurgronje, Arnhem: Stichting Vrienden van Bronbeek.

— (1996) "Snouck Hurgronje (1857-1936)", Facta. Sociaal-Wetenschappelijk Magazine 4(2):6-9. (2002) "Anthropology, the Study of Islam, and Adat Law in The Netherlands and the Netherlands East Indies, 1920-1950", in Vermeulen \& Kommers, eds, Tales from Academia, pp. 673-694.

Van den Berg, L.W.C. (1874) De beginselen van het Mohammedaansche recht, volgens de imam's Aboe Hanifat en asj-Sjafe'i. Batavia: Bruining \& Wijt.

Van der Velde, Paul (2002) "The Indonesia Specialist P.J. Veth (1814-1895): Founder of the First Chair of Anthropology in The Netherlands (1887)", in Vermeulen \& Kommers, eds, Tales from Academia, pp. 647-672. 
Van Maanen, John (1988) Tales of the Field. On Writing Ethnography. Chicago: University of Chicago Press.

Vermeulen, H.F. (1996) Taal-, land- en volkenkunde in de achttiende eeuw. Leiden: Oosters Genootschap in Nederland.

Veth, P.J. (1854-1856) Borneo's Wester-Afdeeling: Geograpisch, Statistisch, Historisch. 2 vols, Zaltbommel: Joh. Noman.

Vermeulen, Han and Jean Kommers, eds (2002) Tales from Academia. History of Anthropology in The Netherlands. 2 Vols. Saarbrücken: Verlag für Entwicklungspolitik.

Von Benda-Beckmann, Franz and Keebet von Benda-Beckmann (2002) "Anthropology of Law and the Study of Folk Law in The Netherlands after 1950", in Vermeulen \& Kommers, eds, Tales from Academia, pp. 695-731.

Wertheim, W.F. (1972) "Counter-insurgency at the turn of the century — Snouck Hurgronje and the Acheh War", Sociologische Gids 19:320-328.

Westenenk, L.C. (1928) Waar mensch en tijger buren zijn. 's-Gravenhage: Leopold. 